\title{
Invisibilising the Victimised: Churches in Manicaland and Women's Experiences of Political Violence in National Healing and Reconciliation in Zimbabwe
}

\author{
Molly Manyonganise \\ mollymanyonganise@yahoo.com
}

\begin{abstract}
Zimbabwe's political history from 2000 to the present epoch has been characterized by violence. This violence reached its peak in 2008 when ZANU $\mathrm{PF}$ was defeated at the polls by the opposition party, MDC-T. The violence resulted in hundreds of people losing their lives while many more were maimed, displaced and/or sexually abused. In this context of political violence, various church groups emerged as the church in Zimbabwe broke its culture of silence and sought to condemn the deployment of divisive politics and the use of political violence as a means to political gain. One such group that emerged in 2000 is a forum of churches in the province of Manicaland called Churches in Manicaland (CiM). From the onset, CiM sought to bring healing to victims of political violence as well as reconciliation of communities in Manicaland through a number of activities. The 2008 political violence resulted in the signing of the Global Political Agreement in which the issue of national healing and reconciliation became officialised and critical national institutions (the church included) were implored to play their roles meaningfully. However, scholars on national healing and reconciliation have noted how gender is often not part of reconstruction processes in post-conflict nations. What this paper seeks to do is to evaluate CiM's approach to gender in its participation in the national healing and reconciliation process in Zimbabwe, both at an unofficial level from 2000 and at the official level from 2008. Drawing on original empirical research (focus groups and interviews), the paper shows how CiM has adopted a general approach to the national healing and reconciliation
\end{abstract}


process, which has made women's experiences of political violence invisible. It is envisaged that this is one way of informing the church to bring to the 'centre' women's experiences of political violence.

Keywords: Women, Womanist perspective, Churches in Manicaland, invisible, political violence, national healing, reconciliation

\section{Introduction}

It is generally acknowledged that women's perspectives are not adequately taken into account during transitions from political violence to peace (Manjoo 2004; Nowrojee 2005; Secco 2008). This is a problem for all parties and groups participating in these processes. But for religious actors, this problem can be even more acute: many religions are patriarchial and women are explicitly or inadvertently excluded from leadership positions. This means that faith-based peacebuilding organizations often systematically exclude women's perspectives. Drawing on original empirical research of a faith-based organization in Zimbabwe, Churches in Manicaland (CiM), this article demonstrates how women victims have been excluded from their services and activities. It argues that this exclusion has made these women invisible: although CiM is a relatively effective advocate for victims on a regional (and even national) scale, they have failed to articulate how women have suffered differently and disproportionately from political violence. CiM is not the only organization to fail to include women's perspectives. All over Zimbabwe, women's experiences of violence - and their contributions to healing and reconciliation - have been overlooked or minimized. But what can be gained from a detailed case study of CiM is insights into why women's perspectives have been excluded, even by the most well-meaning of actors. Understanding the various factors that contribute to women's exclusion can provide insight into how organizations such as $\mathrm{CiM}$ can improve their practices and ensure that women's voices are heard.

\section{Methodology}

The research is qualitative in nature. As alluded to earlier, this paper is based on empirical data gathered in Mutare Urban and Mutare Rural for one month in May 2015. These interviewees were drawn from Churches in Manicaland 


\section{Molly Manyonganise}

officials as well as women survivors of political violence, women and men who witnessed violence against women. In terms of the sample, the researcher for this study interviewed CiM officials, traditional leaders in Manicaland as well as female survivors of political violence and those women and men who witnessed violence and are active in CiM's activities. The sample for the interviews comprised 13 CiM officials ( 8 men and 5 women), 9 female victims of political violence taken from Mutare Urban as well as Mutare Rural and these were interviewed separately, 10 women who witnessed violence also sampled from Mutare Urban and Rural and these were put into one focus group, 3 men who were active in CiM's activities and among them was one traditional leader from Mutare Rural were also interviewed. CiM Steering Committee members were not accorded anonymity because they felt that it was already in the public domain that they were engaged in national healing and reconciliation process. As such, the use of their actual names would not put them into any danger. However, interviewees from the communities in which CiM operates especially the victims/survivors of political violence requested that their actual names be not used. I had to use codes for them so that their lives would not be endangered.

\section{Women under Siege: An Overview of Research on Women and Political Violence}

It needs to be noted that in conflict zones, women are the majority of victims to experience sexual, physical, socio-economic, psychological as well as emotional violence. Much of the literature on women and political violence are sated with this evidence that women are the majority of victims during most conflicts. It is, however, not possible within the context of this paper to give an exhaustive review of literature on women and political violence. As such, I seek to draw attention to some of the scholarly works in the field.

In a book chapter entitled Justice for Women Victims of Violence: Rwanda after the Genocide (2000) Nowrojee and Ralph discuss how sexual violence assume gender-specific forms, like sexual mutilation, forced pregnancy, rape or sexual slavery. They posit that in a conflict situation, being female is in itself a risk factor leading women and girls to be targeted for sexual abuse on the basis of their gender regardless of their age, ethnicity or political affiliation. They also argue that rape and sexual assault of women in situations 
of conflict are widely committed but seldom denounced, because it is viewed as the spoils of war and not as illegitimate acts that violate humanitarian law. In such situations, the perpetrators of the sexual violence are not punished for their crimes. In their analysis of the effects of rape, Nowrojee and Ralph posit that the victim of rape is dehumanised, so is her family and community. In order to avoid the humiliation of the individual, family and community, in most cases, the rape is concealed. The authors, however, argue that the 'silence and impunity about abuses against women hides the problems that devastate, and sometimes end, women's lives' (2000:163). Women themselves do not speak out about the sexual abuses for fear of being stigmatised. They also highlight lack of political will to document human rights violations against women by governments as a major stumbling block to prevent and remedy the sexual abuse. Nowrojee and Ralph categorise rape as a violation of International law, a war crime, a crime against humanity, a genocidal crime and a form of torture. Focusing on Rwanda, the authors expose how the security forces in that country as well as the heads of militia, directed or encouraged both the killings and sexual abuse of women. The effects of rape are listed as social stigmatisation, poor physical and psychological health, unwanted pregnancy and poverty. The authors also indicate how women encounter economic difficulties after conflict especially after losing relatives who acted as breadwinners. In addition, they explained how Rwandan survivors of sexual violence are particularly troubled by the lack of accountability for the abuse they suffered. Their desire is to see the perpetrators of the violence against them held responsible.

Nowrojee and Ralph's theorisation of violence, though focusing on the Rwandan experience is very relevant for the Zimbabwean context, hence, for this paper. This paper draws from the critical insights on the silence of women's experiences of sexual violence by both critical institutions as well as the victims themselves; and the impunity that is accorded the perpetrators of sexual violence especially by national legal systems. What is also significant about this work is the exposition of how political governments ignore what women go through during conflict primarily because they are complicit in the violence. This paper also finds Nowrojee and Ralph's work vital because it delineates the causes that lead women to be sexually abused as ethnicity and political affiliation.

In a book titled Sexual Violence in Africa's Conflict Zones (2011), Pre- 
scott and Madsen grapple with the issue of sexual violence against women and children in those parts of Africa that are riddled with conflict. The main focus is on countries like the Democratic Republic of Congo and Sudan though a comparative analysis with the United States of America is done. Of note is the acknowledgement by the editors of this book that civilians in Africa's conflict zones, particularly women and children are often vulnerable to sexual violence, including rape, mutilation and sexual slavery. The narrations given in Chapter 5 of the book are telling of women's experiences in conflict situations. For example, the now famous story of the Congolese girl, Lumo who was raped by over 50 men in one day and has had to undergo nine operations of the fistula is horrendous.

Coming to Zimbabwe, in research carried out by AIDS-Free World titled Electing to Rape: Sexual Terror in Mugabe's Zimbabwe (2009) it was revealed that in Zimbabwe since 2000, women have suffered sexual violence. Aids Free World interviewed seventy-two Zimbabwean women who are victims of rape/gang rape and other forms of sexual abuse during Zimbabwe's election periods. An analysis of the testimonies given by the women indicates that some of the women ended up getting infected with the HI virus while others got children from the rapes.

The Zimbabwe Doctors for Human Rights (ZDHR) and the Research Advocacy Unit (RAU) produced a report titled No Hiding Place: Politically Motivated Rape of Women in Zimbabwe (2010) in which they traced the occurrence of politically motivated sexual abuse of women in Zimbabwe from 2001 to 2008. They recorded that the sexual abuse includes 'extreme violence, gang rape and insertion of objects- bottles and sticks into the women's genitals'. This is supported by a report produced in the Human Rights Bulletin entitled Gender-based Violence in Zimbabwe which alludes to the fact that women experience violence in the form of rape and concubinage during Zimbabwe's elections. In another report published in 2011 titled Politically Motivated Violence against Women in Zimbabwe 2000-2010: A Review of the Public Domain Literature, RAU traces the occurrence of politically motivated violence to the pre-colonial era. It notes that reports on political violence produced in Zimbabwe before 2000 lack a gendered perspective. This is really important as it brings into perspective society's lack of commitment to issues that directly affect women such as political violence. 


\section{Women and Political Violence in Zimbabwe}

At the dawn of the new millennium, Zimbabwe faced a number of challenges in the social, economic and political arenas. These ranged from HIV and AIDS, effects of the Economic Structural Adjustment Programme which led to economic decline, the Fast-track Land Reform Programme (FTLRP) which started in 2000, electoral violence that characterize the elections of 2000, 2002, 2005 and 2008 as well as Operation Murambatsvina of 2005. This has come to be known as Zimbabwe's crises and a number of scholars have done an indepth study of these. A number of scholarly works have been published on the Zimbabwean crises, among them Chirongoma, 2009; Chitando \& Togarasei, 2010; Masunungure, 2011; Mhiripiri, 2008; Mlambo, 2008; Ndlovu-Gatsheni, 2012; Raftopoulos, 2009; Shale, 2006; Sachikonye, 2002, 2003, 2009, 2011.

One of the arguments of this paper is that any discussion on the Zimbabwean crises especially the political one, would not be complete without considering its gendered dimension with a particular focus on how women were affected by the political violence that ensued in the various historical episodes that characterise the Zimbabwean nation in the new millennium. It is disheartening to note that many scholars who have written about political violence in Zimbabwe from 2000 have not paid much attention to the gender dynamics of the period. Ranchod-Nilsson (2008:647) posits that the gender dynamics of this period are not fully understood, but there is evidence of women becoming targets of sexual violence because of their association with the Movement for Democratic Change (MDC). Moyo (2013:19) locates the general silence on women's experiences of political violence from 2000 within the broader framework of the whole side-lined narrative of women who at different epochs have been silenced in attempting to expose abuses by key political male figures who were seen as indispensable for different political goals. The Human Rights NGO Forum (2013:10) then pinpoints patriarchy as the major culprit in this whole exercise. It argues that 'Zimbabwe as a patriarchal society allowed the conflict to be a space where perpetrators committed gender-based violence including rape against women as part of the overall strategy of violence' (2013:10). Patriarchy as a social-political order is based on male hegemony through dominance and denigration of other experiences; it concentrates power in public and private spheres within the male (Ayiera 2010:12). In this case, women's bodies become sites where these struggles for power are manifested. 
In this case, we need to see women as the major victims of the Zimbabwean political violence. Though women, men and children were victimised in this violence in Zimbabwe, there is a way in which women were uniquely victimised, that is through rape and other forms of sexual violence. For example, in the course of the violent seizures of land, women who were workers in the farms encountered sexual violence from the youth and war veterans. It has been widely noted by various scholars that violence against farmers was practically encouraged while a climate of lawlessness ensued in many areas and rape became increasingly common, making women more vulnerable to HIV infection. One of the research participants, Joyce Simango who is one of the CiM officials indicated that she had personally met a woman from a farm in Chimanimani who had been raped in 2000 (Interview with Joyce Simango in Mutare Urban, 25 May 2015).

The issue of sexual violence against women runs across all the electoral periods from 2000 and also occurred in the wake of Operation Murambatsvina. Bhatasara (2011:320) agrees that women farm workers suffered different forms of violence and that the chaotic nature of the FTLRP left scars on some women across the country. In 2006, a report produced by the Zimbabwe Torture Victims on Operation Murambatsvina showed a 'considerable rise in the incidence of rape and other forms of sexual abuse since 2000 , indicating that rape and other forms of sexual violence had risen to between 12-30\%' (Zimbabwe Torture Victims 2006:4). Various studies have shown how rape and other forms of sexual violence became tools of punishing opposition supporters since 2000. For example, Bastick, Grimm and Kunz (2007:67) argue that,

After 2001, rape and sexual abuse became more common place. Rapes often occurred in front of neighbours or family members as a form of punishment, leaving an impact on a wider group of people than just the individual concerned.

In reference to the bases that were set up by the militia and war veterans, they further posit that 'women were abducted and raped in pro-government militia camps, men were forced by militia to commit sexual assault on other men and women, and people were sexually assaulted in public' (Bastick, Grimm \& Kunz 2007:67). Human Rights Watch moved around the country during the 2008 violent period and reported that ZANU PF militias, the army and 
supporters had erected bases and quite a number of these were in Manicaland. For example, eleven of these bases were in Chipinge East and Central alone. Many women who were taken to these bases were physically and sexually abused at times for days and weeks (Aids Free World 2009:16). Aids Free World (2009:23) captures an incident in Manicaland in which one young girl was locked up and raped everyday by different men. The Research and Advocacy Unit (RAU) and Zimbabwe Association of Doctors for Human Rights (ZADHR) in 2010 produced a report in which they traced the occurrence of politically motivated sexual abuse of women in Zimbabwe from 2001 to 2008. They recorded that the sexual abuse includes 'extreme violence, gang rape and insertion of objects- bottles and sticks into the women's genitals'. In the Mutasa district of Manicaland province, Pauline Moyana was gang raped by four ZANU PF militias at night, just outside their base during the 2008 elections and this was punishment for her support of the MDC (Makanga 2008). Aids Free World (2009) interviewed seventy women who were rape victims of the 2008 political violence and two witnesses of these rapes. In these interviews, it found out that victims of these rapes were aged from five years to elderly grandmothers. It corroborated RAU and ZADHR report that gang rapes were common. Aids Free World further reveal that 'many women were forced to watch their husbands, children, and parents killed or tortured before they were raped' (2009:12). This was corroborated by all the research participants for this paper. For example, one of the woman survivors of political violence from Mutare Rural said women were raped, their livestock confiscated and their homes burnt down. Some also had their daughters raped at the bases. She said:

Ndiri mugari wemuno maZimunya. Pamhirizhonga ya2008 ari manheru, takabudiswa mumba tikaendeswa kubhesi kumadhirihori. Tainzi tiimbe uye zvainzi vanamai vanofanira kuuya nehuku nechikafu. Anenge atadza kuuya nehuku aipiwa punishment yekuzodziunza dzave mbiri. Ini pamba pangu vakapisa imba imwe chete, vakatora mbudzi mbiri nehuku dzese. Ndakaudza mapurisa asi haana zvaakaita (I am a resident here in Zimunya. During the political violence of 2008, at night, we were made to go out of the house and were taken to a base at the drying halls. We were made to sing and it was said mothers should bring chickens and food. Anyone who failed to bring the chicken was given the punishment of bringing two 
chickens. At my home, they burnt one hut, took two goats and all the chickens. I reported to the police but they did nothing) (Interview with Interviewee D in Mutare Rural, 24 May 2015).

The sexual violence that women experienced was meant to intimidate, humiliate and punish them and by extension, their families for their political affiliation (Aids Free World, 2009:13). Another survivor said,

I was beaten together with my ailing daughter and her child. The windows to my house were all broken. My daughter has since died. At that time my granddaughter could not attend school because she was injured. I am still pained. I know the people who did this to me but I can't do anything. Even then, nothing would take place if you report (Interview with Interviewee C in Mutare Urban, 23 May 2015).

Some women were raped when their husbands had fled from the violence leaving their wives at home alone. The Church and Civil Society Forum in Zimbabwe (2012:21) notes that the absence of men increased women's vulnerability and compromised their security and that the abuses perpetrated against them was meant to force the men who had fled to return.

The rapes left women vulnerable to HIV and AIDS. For example, nine of the women interviewed by Aids Free World (2009:12) 'believe that they were infected with HIV and AIDS as a result of the rapes, and an additional seventeen women also tested HIV-positive in the months following the rapes, raising the possibility that rapists infected them'. The women who witnessed political violence against women and were interviewed in a FGD highlighted three cases that show the severity of violence experienced by women after the 29 March 2008 elections. One of the FGD participants narrated a case in which a woman was humiliated at one of the rural bases in Zimunya. She said the woman was made to remove all her clothes and was made to roll in the mud while she was being beaten. She was forced to chant the ZANU PF slogan. After beating her, she was told to leave the base while in the nude. Only one woman was courageous enough to give her a wrapper to cover herself. The other case is that of a woman from Bocha who fled her home from ZANU PF supporters and lived in the bush for some days. Her husband was working in Harare. Her property was taken away. However, the problem now is that her marriage has broken down because the husband is questioning why she ran 
way to the bush and not to his relatives. The husband has left the family and the woman is struggling to take care of the children. The third case is that of two women gang raped by ZANU PF militia at one of the bases in Marange. They were infected with HIV but they never told their husbands about the rapes. The husbands are now late. The women are now coming out in the open about the sexual abuse after the death of their spouses (Interview with FGD participants, in Mutare Urban).

In addition to the infection, some women fell pregnant due to the rapes and now have to look after children who are at times sick themselves. Operation Murambatsvina disrupted access to information on HIV prevention and treatment to many women who were living with HIV and AIDS. Chirongoma (2009:86), argues that an estimated ' 79500 persons over 15 years of age living with HIV [were] displaced', consequently leading to increased vulnerability and risk to gender violence and risky sexual behavior. Women and men failed to continue with their Anti-Retroviral treatment leading to the loss of life of several of them.

Throughout the years of political violence in Zimbabwe from 2000, women have suffered displacements. During the FTLRP, women farm workers were displaced from their areas of work, with some relocating to urban, periurban or rural areas. In a research in commercial farming areas, Sachikonye (2003:45) ascertained that due to the FTLRP, most female farm workers had left the farms, though at the time he could not establish where these women had gone to or how they were living. He, however, established that due to the displacements, the impact of job losses on women had been profound, especially because a large proportion of them were single or single parents, widowed or separated. The condition of women was compounded by the politics of exclusion that accompanied the FTLRP. Despite some women having participated in the land invasions, they were not considered for land ownership. Instead they were forced to offer sexual favours in exchange for their names to be put on the redistribution list. A study on Nyabamba in Manicaland Province by Chingarande, Mugabe, Kujinga and Magaisa (2012) established that there were glaring gender disparities in land ownership. Goebel cited in Bhatasara (2011:320) argues that the gendered nature of the violence during the FTLRP has not been addressed as there were no frameworks for women victims of violence during the programme to seek justice and recourse.

When Operation Murambatsvina was executed, a lot of families who 
were staying in the demolished structures were displaced and the majority of them relocated to the rural areas. From figures released by the United Nations (2005), about 700000 people were directly affected by the operation. The Church and Civil society Forum in Zimbabwe (2012:15) posits that through Operation Murambatsvina, 'women were greatly affected as they had to take care of their children and extended family members in the open, on the streets'. The demolitions also affected the livelihoods of a number of women. According to CCSF (2012:39) women were disproportionately affected by Murambatsvina especially widows who depended on rentals for survival and women in the informal sector. Before the execution of Operation Murambatsvina, women depended on flea markets and vegetable vending to make a living. This came to a sudden halt due to the operation. Human Rights Watch cited in Chibisa \& Sigauke (2008:43) contends that women were the worst affected since they did not own properties in rural areas and depended on flea market trading in urban areas for their livelihood. Most of the women interviewed lamented the destruction of livelihoods by the operation since most of their wares were confiscated, destroyed or burnt. This was confirmed by all the CiM officials. Thus, Vambe (2010:76) argues that,

Operation Murambatsvina targeted this informal sector and undermined the economic rights and legal status of women. Young black women not yet married or those in marriages out of community of property who ran the thriving flea markets were hit hard by Murambatsvina when the authorities confiscated their goods. Without anybody to turn to, and unable to raise capital to restart their businesses, most of the women lost their economic independence and some were forced to choose the hard option of prostitution.

These views by Vambe are supported by the Human Rights Watch (2005:27) which noted the plight of widowed women and mothers with children living with disabilities. In its analysis, the Human Rights Watch (2005:28) argued that 'displaced women and girls were also vulnerable to various forms of abuse and harassment including sexual abuse and domestic violence'. Thus, the operation induced unprecedented scales of poverty, homelessness and vulnerability with both immediate and long-term effects (Hammer 2008:31), especially for women.

From 2000, the violence during elections also caused women to flee 
their homes in the rural areas and seek refuge in the cities and towns. The Human Rights Watch posits that the 2008 political violence displaced more than 36000 people. In Manicaland, it recorded about 500 people, men, women and children who were sheltering in the MDC's regional headquarters in Mutare to try to escape state-sponsored violence. All of the women interviewed by Aids Free World had fled the 2008 political violence and were then living in South Africa and Botswana. It is in such a context that new church bodies emerged in Zimbabwe.

\section{Churches in Manicaland: A Voice Emerging in the Context of Political Violence}

CiM was formed in 2000 as a forum of church leaders that is not aligned to any particular political interest group or party. All the CiM officials and African Initiated Church (AIC) members interviewed for this paper gave political violence as the major reason that led to the formation of the Forum. As such, several church and lay leaders from all major denominations and ecumenical church-based organisations began to have regular meetings. They were responding to a specific political situation and at that point, the objective was not to establish an ecumenical forum which would continue to operate after the 2000 election. However, the churches and church organisations discovered later that the root causes of the violence were not going to disappear easily and the churches had a lot of work to do to strengthen just peace in Manicaland. Thus, the notion of CiM as a permanent forum emerged out of an intense period of activity resulting in the Forum becoming a cooperative meeting space rather than a formally constituted organisation.

As such, the Forum is a space which is open to participation on a voluntary basis by church and lay leaders from all churches existing in Manicaland. Ganiel and Tarusarira (2014:69) view CiM as 'an 'ecumenical' gathering of members from Christian denominations and organisations in the province of Manicaland'. In the same vein, Chitando and Togarasei (2010:156) view the Forum as providing an ecumenical platform for responding to political, social and economic issues in the province and in the country.

At its inception in 2000, CiM had a membership of 40 churches and church organisations affiliated to it and the churches are made up of Catholics, Protestants, Pentecostals and AIC members. What can be deduced from this composition is that $\mathrm{CiM}$ has tried to bring together Christians of different 
doctrinal backgrounds. The Forum does not have a formal structure, but is run by a steering committee which is made up of men and women leaders of the churches that are operational in Manicaland. Adopting this informal structure has enabled CiM to avoid undermining the existing church membership organisations to which CiM participants already belong. In a way, as indicated by research participants from the Forum, this was also a way of subverting political victimisation.

In 2007, CiM appointed a coordinator. As one looks at some of the names of the people who constitute the steering committee of CiM one finds that they are also members in other ecumenical bodies in Zimbabwe. For example, Bishop Patrick Mutume of the Catholic Church is also a leader in the Zimbabwe Catholic Bishops Conference (ZCBC). In trying to find out why CiM emerged in a context where other bodies such as the ZCBC, Zimbabwe Council of Churches (ZCC) and Evangelical Fellowship of Zimbabwe (EFZ) were already operational, the Coordinator of the Forum responded thus:

We had dealt for a long time with these organisations and had become tired of the bureaucracy. Most of these organisations have their headquarters in Harare and it would take years for an issue sent to Harare to be solved. We, therefore, needed space where issues in Manicaland could be dealt with expeditiously without necessarily referring them to Harare (Interview with Abel Waziweyi 21 May 2015).

It is in this vein that Tarusarira (2014:88-89) locates the emergence of CiM within the broader context of an irrelevant theodicy of mainline churches. He argues that mainline churches have held a theodicy that has legitimised perpetrators of political crisis in Zimbabwe. From his perspective, the theodicy of mainline churches did not provide answers to questions of violence, suffering and reconciliation. Ganiel and Tarusarira (2014:68) argue that the emergence of CiM needs to be justified with the perceived ineffectiveness of groups like ZCBC, ZCC and EFZ. In such a context of irrelevance and ineffectiveness, new religio-political organisations emerged to offer a new or alternative theodicy informed and characterised by radical, scripture-based analysis of the crisis. Using sociological theoretical perspectives, Tarusarira (2014), Ganiel and Tarusarira (2014) have classified CiM under religious nonconformist groups. Religious non-conformism has been defined as 'not just a 
stubborn and arrogant departure from norms but 'a potential resource for alternative ways of interpreting the meaning of life, establishing social values and creating ways of life', which makes it an element of cultural tension and dynamism' (Ganiel \& Tarusarira 2014: 137).

When it was incepted, CiM had two key areas of focus namely human rights and governance. In these areas, CiM sought to bring human rights issues to the awareness of the communities in Manicaland as well as empowering church leaders in issues of governance in order to enable them to intervene in crisis situations. The Forum also sought to bring political and traditional leaders at the community level to discuss issues. Throughout the years, the areas of focus have increased as the Forum seeks to be relevant to emerging issues in Zimbabwe. In order to be effective, CiM has different committees that work on different areas. The committees are made up of volunteers and report to the Steering Committee and their activities are then shared with the larger group of church leaders (Waziweyi 2011:59). One of the areas in which CiM has sought relevance is national healing and reconciliation. After the formation of the GNU in 2009 and the establishment of the Organ on National Healing, Reconciliation and Integration (ONHRI), CiM has intensified its programmes which are meant to bring healing and reconciliation to communities in Manicaland. Hence, from 2000, CiM has involved itself in a variety of activities some of which are going to be shown below.

\section{CiM in the National Healing and Reconciliation Process}

In my analysis of CiM's interview responses by CiM Steering Committee officials, it was evident that the Forum has been very active in dealing with political violence as well as in bringing healing and reconciliation to communities in Manicaland. Some of the activities among others that CiM is involved in are: holding workshops with traditional leaders, provision of safe houses, free medical treatment and legal aid to victims of political violence, holding peace prayer rallies and night prayer vigils, organising peace soccer and netball tournaments, monitoring of food distribution to mention but a few. All these activities are crucial for CiM's participation in the national healing and reconciliation process. Commenting on the workshops, Ganiel and Tarusarira (2014:70) are of the view that the workshops that are run by CiM are important to facilitate civic values needed for a better Zimbabwe. Moreover, Waziweyi (2011:101) says: 
peace tournaments are a new phenomenon that is meant to create interaction between two groups of people, the victim and the perpetrator of violence... These are community based initiatives which devise parameters of recovering the truth.

The tournaments have created spaces where the Forum can teach communities about political tolerance especially in the rural areas, where political violence has been vicious, as well as the need for political opponents to accept defeat with dignity. The tournaments also provide opportunities for communities torn by conflict to meet each other on a platform that is not political. In their analysis of the significance of sport in Rwanda's post-genocide reconstruction processes, Dills and Muyango (2008:56) view sport as spaces for communion and argue that in Rwanda, it was used as a means of communication for transmitting messages about a culture of peace. FGD participants for this study indicated that the peace tournaments eased tensions between community members and enabled people with opposing views to interact with each other after the tournaments. On the other hand, though the prayer rallies are presented as an 'innocent' call for peace in Zimbabwe, they are in a way a subtle call for the politicians to account for the political violence that the general public continues to experience.

\section{CiM and Women's Experiences of Political Violence: Responses from the Field}

In response to the question on whether CiM prioritises women's experiences of political violence, the Steering Committee members of CiM were not agreed as to what they had done to address this issue. Pius Munembe said he was not very sure where they are, but remembers in some of the meetings that they had identified women and the youth as those groups that needed to be heard and had resolved that these should benefit from livelihood programmes. At the end of the interview, he, however, confessed that as a Forum, they had not addressed women's issues. In addition, he said that even if they had wanted to prioritise women's experiences of violence in this process, it is difficult to have women attend meetings and articulate their experiences. He said most women require the permission of their husbands to attend and for those that do attend, it becomes difficult for them to express themselves. 
Abel Waziweyi said:

Not really. We have not focused on women, maybe because the church leadership is male dominated. We have been looking at communities as a whole.

For Waziweyi, the challenge they face in putting the experiences of women at the fore of the national healing and reconciliation process is financial. They have not so far allocated any funds for women's programmes due to budget constraints. He, however, indicated that the failure to mainstream gender in their activities was 'purely administrative rather than the lack of zeal'. To this end, he said 'we need a shift in our thinking so that we have programmes specifically for women so that we focus on women specifically'.

Nyarota said:

I don't think there has been a specific intention to say we are attending to women. CiM attended to victims in general, anyone who needs support. Gender has not been part of the agenda.

Furthermore, Peter Rore said:

Not fully. We responded to violence generally. There was one meeting for women, but it was not well-attended. (Interview with Peter Rore in Mutare Urban, May 2015).

Rore said that at times it is difficult to focus on women because the national healing and reconciliation process has happened on a bigger scale. He also said the fact that they do not have a gender desk has led CiM to look at survivors of violence as a collective group.

Other CiM Steering Committe members shared the above views. For example, Mutambara said national healing and reconciliation has been at the heart of CiM, but she was not sure whether gender has been its focus. The reason for this, she said could be that there are not a large number of women in the Steering Committee. She, however, noted that of late, there has been a number of women coming to join the Steering Committee. She also noted that in its activities in the communities, CiM has also targeted leaders and these leaders happen to be men. She hopes that if the church and communities can 
have more women leaders, they can bring the gender-dimension to the national healing and reconciliation process. Specifically, she hopes that in CiM the more women they have, the more the stories they will be able to capture of women's experiences of political violence.

Philemon Chikafu said:

CiM failed the women. We created awareness but did not implement healing programmes on the ground especially for women.

He said the space is overcrowded by men to the extent that women's voices are not being heard. From his perspective, men think that their language is the women's language or the bishop thinks that his language is the women's language. He gave the analogy of the kitchen, the well and that of gathering fire wood. From this analogy, he said, these spaces are culturally designated for women. They are spaces where women could share their experiences without any interference from men. He, therefore, argued that the church has failed to provide such spaces to women in the national healing and reconciliation process (Interview with Philemon Chikafu at Africa University in Mutare Urban 21 May 2015).

Shirley Dewolf said they have not specifically looked at women's experiences of political violence in isolation of what men and children went through. From her point of view, the main reason for this could be that most members in the CiM Steering Committee have been men because most of the clergy in churches are men. She also said they are trying to have a broader perspective where they would invite lay members of the church to be part of the Steering Committee so that they would have more voices coming from women. This has not been easy because of the multiple jobs that women do at home which hinder them from attending meetings. She also noted that men have easy access to vehicles which makes it easy for them to attend the meetings which are usually held in the evening. However, she said 'what we are trying to do is to call for a women's only gathering where we intend to get women's voices from all districts and to enable the women to name the challenges that they are facing' (Interview with Shirley DeWolf, 22 May 2015).

Simango confirmed that they have not looked at women in particular and like Dewolf said that 'there is need to have a programme to come up with a workshop so that women would discuss their challenges'. For her, the challenges are that women do not come out in the open about their experiences 
because of fear. She said:

Maybe it's the way they have been socialised. Culture. They are not able. They fear to come out in the open. They say out not exactly what they are going through.

In her opinion, the problem could be that men are the majority of the people in the CiM Steering Committee. She, therefore, said that CiM should not put male pastors in the front of the national healing and reconciliation process especially on issues that concern women. She argues:

women should deal with pastors' wives and lay women in church. Ndivo vanoziva zvevanamai (they are the ones who know what concerns women). The problem is CiM seems to be putting emphasis on the male pastors.

Dangare, Dube, Shatai and Patrick Mutume said that CiM has prioritised women's experiences of political violence in the national healing and reconciliation process. Mutume did not elaborate on how they have been doing this. He, however, said that though they may want women's experiences to be dealt with on a broader scale, they face a number of challenges. He highlighted that in the rural villages most leaders are staunch ZANU PF supporters and they do not want to hear about anything that may prejudice the party. He further said one of the problems of reconciliation is that women are restricted and in his interactions with them, women have been complaining that they had not been given space to talk.

Chipo Dube said:

Tinozvikoshesa zvakanyanya. Tinotsvaga nzira dzekuvabatsira nadzo. Nguva yeMurambatsvina, CiM yakaratidza Kajumulo Tibaijuka nzvimbo dzaive dzakavigwa vakadzi vakawanda vaive vaputsirwa dzimba dzavo nehurumende. Takavapawo zvekudya. (We give them great attention. We find ways of helping them. During Murambatsvina, CiM showed Kajumulo Tibaijuka where a lot of women whose houses had been destroyed were hidden by the government. We also gave them food). (Interview with Chipo Dube, 29 May 2015). 


\section{Molly Manyonganise}

Marian Dangare said they have formed groups of women who were affected by political violence. She said most of these women do not have any livelihoods. In this case, in the Mubatanidzwa weMadzimai, they have formed groups in which women are being encouraged to have savings. She also said in their individual churches they have women's morning prayers, a space where women have the opportunity to testify about their experiences. Women in the CiM Steering Committee take these testimonies and discuss them in the CiM meetings and they are advised on how to help them. The challenge they face when dealing with the women is that women are not free to share all of their experiences of political violence especially sexual abuse. She said most of the women who were raped during the violence choose to keep quiet about it as a way of safeguarding their marriages. She also said they fear the stigma and discrimination that may result from opening up about rape. She also indicated that though they want the women to talk about their experiences, they do not know what to do with them afterwards because they do not have the resources to support the women in the process of healing. For her, it is not only a matter of simply discussing about the political experiences of violence but also about what to do with them (Interview with Marian Dangare in Mutare Urban, 22 May 2015).

Obert Shatai said:

Yes. When we have meetings we call women from the Mubatanidzwa weMadzimai around Mutare in order to equip them about their rights. As CiM, we have also partnered the Ecumenical Church Leaders Forum (ECLF) and have three-day workshops with women and the youth on peace-building (Interview with Obert Shatai in Mutare Urban, 27 May 2015).

He, however, said the challenge they face is that women are very suspicious. After the violence, they fear being questioned why they attend the meetings that we call for. For fear of victimisation women choose to sit back and keep quiet.

\section{The Invisible Women: A Discussion of the Responses}

The dominant narratives of healing and reconciliation in general and the Zimbabwean context in particular makes women invisible. Mckay cited in 
Scanlon (2016:3) notes that reconciliation processes have been overwhelmingly driven by interests that favour the powerful and disenfranchises the vulnerable, while Melandri (2009:14) argues that 'the invisibility of women in transitional justice processes has still not been adequately addressed'. Thus, an analysis of the above responses from interviewees for this paper brings out critical issues about the invisibilisation of women in the whole process of national healing and reconciliation by CiM. It is apparent that CiM has not given particular attention to the ways in which women are affected by political violence in Zimbabwe. One of the major reasons that appear to have led CiM not to prioritise women's experiences of political violence is that the church has to a large extent remained a patriarchal institution. The majority of CiM officials confirmed that the Forum's Steering Committee is overcrowded by men who, whether by design or not, have conveniently ignored the uniqueness of how women experience political violence in the national healing and reconciliation process. Njoroge (2009:5) avers that 'the subordination of women is one common thread that runs through many religious communities, in the Bible, in African religion and culture, and in most of the world's cultures and religions'. In this case, of the five women interviewed from the Forum, only one is an ordained minister from the United Methodist Church. Thus, when women are absent or few at the decisionmaking level, it becomes difficult to have their real concerns correctly articulated. There is also a general tendency to overlook those experiences that really matter for them because 'patriarchy undervalues female experiences and knowledge' (Kivai 2007:22). As such, Chikafu's images of the kitchen, the well and firewood gathering is meant to dismantle patriarchy within the churches by creating spaces where women can afford to air their concerns, painful experiences and aspirations. Chikafu's analysis that the patriarchal voice of the men and the bishop in church need not be regarded as the be-all and end-all of all that is to be said needs to be taken seriously as it seeks to provide spaces where women's voices are also heard.

The impediment of patriarchy is also prevalent within the communities in Manicaland. Study participants from CiM indicated that in cases where they have tried to include women in some of the programmes, a few or none of them turned up. The major reasons provided were that women require the permission of their husbands, due to their expected roles of caring for children it is not always possible for them to attend and also that when it comes to CiM meetings, the time may not be friendly to women because the meetings are 


\section{Molly Manyonganise}

mostly held in the evening. All these restrict and exclude women from fully participating in healing and reconciliation programmes because patriarchal gender roles confine them to the home. Thus, confirming Manyonganise's view that 'in African societies, women have their physical mobility controlled' (2010:16).

The absence of a gender desk or committee on gender points to the lack of a gender perspective to national healing and reconciliation by CiM. What this has done is to create a distance between the Forum and women at the grassroots who are the main victims/ survivors of political violence. When the Forum holds workshops in the rural areas, it deals with traditional leaders who are men. The whole process then becomes a men's affair- a process by men for the men. The resultant factor has been the lack of a gender-focused budget for CiM as enunciated by Waziweyi.

The other issue that comes out clearly is the conceptualisation of healing as a national phenomenon. The meaning of the concept of "national healing' is highly debatable. The term healing accompanied by the adjective 'national' is vague. What makes the healing endeavour problematic is the fact that it does not take into cognisance peculiarities of individual cases, but 'nationalises' the healing process in one stroke. Its effectiveness becomes questionable especially when one looks at how marginalised groups such as women are catered for in a 'nationalised' healing process. Nyarota confirms this when he said that as CiM, gender was never part of their agenda since they adopted a victim-centred approach to dealing with all the victims of political violence. From the views of Chikafu and Rore, we hear sentiments that the process of national healing and reconciliation needs to start small, that is, from families, communities until we get to the national level. Segalo (n.d) confirms this when she says that

people's personal memories are trivialised when the state/government seeks and focuses on national healing while disregarding individual experiences. This may lead to a 'controlled' form of remembering which does not take into account the differences between types of suffering experienced by individuals, and particular contexts in which the suffering is experienced.

The issue of political violence and its effects on Zimbabweans, especially women, has not gained prominence in the country's official narrative. A critical 
analysis of the national healing and reconciliation process shows that no ground work has been done to ensure that voice is given to women survivors of violence at the national level. Moreover, the Forum itself has enforced silence on the women survivors because it fears retribution from the state and it cannot guarantee the security of those who want to break the silence. From Dangare's response, the Forum is also in a dilemma because without enough material resources, it is afraid of capturing women's experiences of political violence with no guarantees of meaningful help. However, Nowrojee and Ralph (2000:163) conclude that 'silence about abuses against women hides the problems that devastate, and sometimes end women's lives'. Apart from enforced silence, women survivors also remain quiet about their experiences of political violence. Simango blamed culture and the way women have been socialised as the causes of their general silence especially on issues of sexual violence. What makes the issue of rape in relation to the church complex is the fact that the church moralises the sex and sexuality discourse. As a result, it becomes difficult for the CiM leaders, most of whom are men and the survivors of violence, the majority of whom are women, to come to a place where they can talk about issues of sexual abuse. As shown above, Simango lamented the incapacitation of the male church leaders in dealing with women's issues and implored them to leave it to their wives and other lay women with whom women in church may feel free to share their experiences of political violence. On the other hand, from Dangare's response, we can see that in the absence of male leadership, women can subvert patriarchy and come up with practical ways to healing and reconciliation, thus, confirming Jacobs' view that with their collective responses to the economic, social, and political issues, ordinary community women can quietly challenge existing conditions of gender inequality (2013:31). Though at a smaller scale, the savings clubs initiated by women to some extent help in economically empowering the women survivors of political violence.

\section{Conclusion}

This paper sought to show how CiM is dealing with women's experiences of political violence in the national healing and reconciliation process in Zimbabwe. In order to achieve this, the paper reviewed literature on women and political violence as well as discussing the activities of CiM in response to political violence in Manicaland. Furthermore, it explored the views of CiM 
officials on how the Forum has dealt with women's experiences of political violence. It showed that women are invisible in the process largely due to the fact that CiM has treated survivors of political violence as collectives. Most of the Forum's activities are not gender-tailored which shows its genderinsensitiveness. This may be a result of the fact that the church has to a large extent remained gender-incompetent which, therefore, provides strong justification for the church to come up with gender-sensitive models for national healing and reconciliation; models which pay particular attention to how women experience political violence.

\section{References}

Aids Free World 2009. Electing to Rape: Sexual Terror in Mugabe's Zimbabwe. New York: Aids Free World.

Ayiera, E. 2010. Sexual Violence in Conflict: A Problematic International Discourse. Feminist Africa 14:7-20.

Bastick, M., K. Grimm \& R. Kunz 2007. Sexual Violence in Armed Conflict:

Global Overview and Implications for the Security Sector. Geneva:

Geneva Centre for the Democratic Control of Armed Forces.

Bhatasara, S. 2011. Women, Land and Poverty in Zimbabwe: Deconstructing the Impacts of the Fast Track Land Reform Programme. Journal of Sustainable Development in Africa 13, 1: 316-330.

Chingarande, S.D. et al. 2012. Struggles within a Struggle: Gender and Land Reform Experiences in Chimanimani District, Zimbabwe. Journal of Social Development in Africa 27, 1: 57-84.

Chirongoma, S. 2009. Operation Murambatsvina (Operation Restore Order): Its Impact and Implications in the Era of HIV and AIDS in Contemporary Zimbabwe. In N. Hadebe \& E. Chitando (eds.): Compassionate Circles: African Women Theologians Facing HIV. Geneva: World Council of Churches.

Chitando, E. \& L. Togarasei 2010. The Church and the 2008 Zimbabwean Political Crisis. African Identities 8, 2: 151-162.

Church and Civil Society Forum 2012. A Study on the Role of the Church in Political Violence in Zimbabwe. Harare: CCSF.

Dills, L. \& J. Muyango. 2008. Church Action in Promoting a Culture of Peace. In Rogers, M.M., T. Bamat \& U. Ideh (eds.): Pursuing Just Peace: An 
Churches in Manicaland and Women's Experiences of Political Violence

Overview and Case Studies for Faith-based Peacebuilders. Baltimore: Catholic Relief services.

Ganiel, G. \& J. Tarusarira. 2014. Reconciliation and Reconstruction among Churches and Faith-Based Organisations in Zimbabwe. In Leiner, M., M. Palme \& P. Stockner (eds.): Societies in Transition: Sub-Saharan Africa between Conflict and Reconciliation. Gottingen: Vandenhoeck \& Ruprecht.

Hammer, A. 2008. Reflections on Displacement in Zimbabwe. Concerned Africa Scholars Bulletin 80: 28-35.

Human Rights NGO Forum 2013. Report on the Second International Conference on Transitional Justice in Zimbabwe. Available at: https://www.ijr.org.za/portfolio-items/second-international-conferenceon-transitional-justice-in-zimbabwe/.

Jacobs, B.L. 2013. Unbound by Theory and Naming: Survival Feminism and the Women of the South African Victoria Mxenge Housing and Development Association. Berkeley Journal of Gender, Law and Practice. 26, 1-2: 19-77.

Kivai, G. M. 2007. The Female Voice and the Future of Gender Relationships in the Nigerian Nation in Chimamanda Adichie's Purple Hibiscus and Half of a Yellow Sun. Master of Arts Thesis. Kenyatta University.

Makanga, D. 2008. Rights-Zimbabwe: Activists Demand Justice for Politically-Motivated Rapes. Inter Press Service. Available at: http://www.ipsnews.net/2008/11/rights-zimbabwe-activists-demandjustice-for-politically-motivated-rapes/.

Manjoo, R. 2004. The South African Truth and Reconciliation Commission A Model for Gender Justice. Paper prepared for the United Nations Research Institute for Social Development Report titled Gender Equality: Striving for Justice in an Unequal World.

Manyonganise, M. 2010. From 'Safety' Zones to Public Spaces: Women's Participation in Sport in Zimbabwe. In Shehu, J. (ed.): Gender, Sport and Development in Africa: Cross-cultural Perspectives on Patterns of Representations and Marginalisation. Dakar: CODESRIA.

Masunungure, E.V. 2011. A Militarised Election: The 27 June Presidential Run-off. In Masunungure, E. (ed.): Defying the Winds of Change: Zimbabwe's 2008 Elections. Harare: Konrad Afenaver Foundation and Weaver Press.

Melandri, M. 2009. Gender and Reconciliation in Post-conflict Societies: The 
Dilemmas of Responding to Large-scale Sexual Violence. International

Public Policy Review 5,1:4-27.

Mhiripiri, N. 2008. The Zimbabwe Governmment's Response to Criticism of

Operation Murambatsvina. In Vambe M.T. (ed.): The Hidden Dimension of Operation Murambatsvina. Harare: Weaver Press.

Mlambo, A. 2008. Historical Antecedents to Operation Murambatsvina. In

Vambe M.T. (ed.): The Hidden Dimension of Operation Murambatsvina.

Harare: Weaver Press.

Moyo, K. 2013. Forbidden Truth: Background to Truth Recovery in Zimbabwe, Challenges, Opportunities and Threats. Paper presented at the Second International Conference on Transitional Justice in Zimbabwe, 913 October 2013.

Ndlovu-Gatsheni, S.J. 2012. Elections in Zimbabwe: A Recipe for Tension or a Remedy for Reconciliation. Wynberg: Institute for Justice and Reconciliation.

Njoroge, N. 2009. Gender Justice, Ministry and Healing: A Christian Response to the HIV Pandemic. London: Progressio.

Nowrojee, B. \& R. Ralph. 2000. Justice for Women Victims of Sexual

Violence: Rwanda after the 1994 Genocide. In Amadiume, I. \& A. An-

Na'im (eds.): The Politics of Memory: Truth, Healing and Social Justice.

New York: ZED Books.

Nowrojee, B. 2005. Your Justice is too Slow: Will the International Criminal

Tribunal for Rwanda fail Rwanda's Rape Victims. United Nations

Research Institute for Social Development, Occasional Paper 10.

Prescott, J.A. \& A.M. Madsen (eds.) 2011. Sexual Violence in Africa's Conflict

Zones. New York: Nova Science Publishers.

Ranchod-Nilsson, S. 2008. Gender, Politics and Gender Backlash in

Zimbabwe. Politics and Gender 4, 4: 642-652.

Raftopoulos, B. 2009. The Crisis in Zimbabwe, 1998-2008. In Raftopoulos, B.

\& A. Mlambo (eds.): Becoming Zimbabwe: A History from the Pre-

Colonial Period to 2008. Harare: Weaver Press.

Report by RAU and ZADHR 2010. No Hiding Place: Politically Motivated Rape of Women in Zimbabwe. Available at: http://lexglobal.org/files/POLITICAL\%20RAPE\%20REPORT.pdf.

Report by RAU. 2011. Politically Motivated Violence against Women in Zimbabwe 2000-2010: A Review of the Public Domain Literature. 
Churches in Manicaland and Women's Experiences of Political Violence

Available at: https://akcampaign.files.wordpress.com/2012/02/politi cally-motivated-violence-in-zimbabwe-2000-2010.pdf.

Sachikonye, L.M. 2002. Wither Zimbabwe? Crisis and Democratisation. Review of African Political Economy 29,91: 13-20.

Sachikonye, L.M. 2003. The Situation of Commercial Farm Workers after Land Reform in Zimbabwe. A Report prepared for the Farm Community Trust of Zimbabwe.

Sachikonye, L.M. 2003. The Situation of Commercial Farm Workers after

Land Reform in Zimbabwe. A Report prepared for the Farm Community

Trust of Zimbabwe.

Sachikonye, L.M. 2009. Between Authoritarianism and Democratisation: The

Challenges of a Transition Process in Zimbabwe. Harare: Institute of

Development Studies, University of Zimbabwe.

Sachikonye, L.M. 2011. When a State Turns on its Citizens: 60 Years of Institutionalised Violence and Political Culture. Auckland Park: Jacana.

Scanlon, H. 2009. Gender and the Politics of Reconciliation. Institute of Justice and Reconciliation, Occasional Paper 19.

Secco, A.D. 2008. Truth and Reconciliation Commissions and Gender Justice.

In Pankhurst, D (ed.): Gendered Peace: Women for Post-War Justice and

Reconciliation. Abingdon: Routledge.

Segalo, P. n.d. Gendered Suffering and the Complexities of Keeping Silent. Available at: http://uir.unisa.ac.za/bitstream/handle/. (Accessed on 15 July 2015).

Shale, V. 2006. Operation Murambatsvina: The Dynamics and Escalation of Zimbabwean Intra-State Conflict. Journal of Conflict Resolution 6,2: 107125.

Tarusarira, J. 2014. Religion in Times of Crisis in Zimbabwe: A Case Study of Churches in Manicaland and its Theodicy of Liberation. In Ganiel, G., H. Winkel \& C. Monnot (eds.): Religion in Times of Crisis. Leiden: Brill Academic Publishers.

Vambe, B. 2008. Murambatsvina's Assault on Women's Legal and Economic Rights: An Interview with a Cross-boarder Trader. In Vambe M.T. (ed.): The Hidden Dimension of Operation Murambatsvina. Harare: Weaver Press.

Waziweyi, A. 2011. An Investigation into the Role Played by Churches in Manicaland in Healing and Reconciliation in Zimbabwe 2000-2010. Master of Arts Dissertation. Africa University. 
Molly Manyonganise

Molly Manyonganise

Department of Religious Studies and Philosophy

Zimbabwe Open University

mollymanyonganise@yahoo.com 